\title{
Imagens do Sul: o documentário contemporâneo na Argentina e Brasil
}

\author{
Ana Amado' e Maria Dora Genis Mourão²
}

I PhD em literatura pela Universidade de Leiden e Licenciada em Ciências Políticas, é professora titular de Teoria e Critica Cinematográfica da Facultad de Filosofia y Letras da Universidad de Buenos Aires. É professora visitante da Duke University e da Princeton University nos Estados Unidos, Universidad ARCIS em Santiago do Chile e na Universidad Nacional Autónoma do México. Obteve a Guggenheim Fellowship. É autora de La imagen Justa. Cine argentino y politica e co-autora de Lazos de famillia. Herencias, cuerpos, ficciones e Espacio para la lgualdad. El ABC de un periodismo no sexista. E-mail: amado3@fibertel.com.ar

2 Professora Titular do Departamento de Cinema, Radio e TV da ECA/USP. Pós-Doutora pela École des Hautes Études en Sciences Sociales-EHESS, Paris. Ensina teoria e prática da montagem tendo montado diversos filmes, entre eles os documentários "São Paulo, Sinfonia e Cacofonia" de Jean Claude Bernardet e "São Paulo Cinemacidade" de Aloysio Raulino. É co-autora do livro Cinema e Montagem, co-organizadora do livro Cinema do Real, é também uma das organizadoras do Catalogo Jean Claude Bernardet, uma homenagem; é corresponsável pela organização editorial do Catalogo/Livro Chris Marker, bricoleur multimídia e do Catalogo/Livro Harun Farocki e a política do olhar. É Presidente do Centre International de Liaison des Écoles de Cinéma et Télévision. E-mail: mdmourão@usp.com 


\section{Resumo}

Partindo do encontro (ou desencontro) entre o subjetivo e o público, articulação comum em boa parte da produção documental, propomos refletir sobre filmes argentinos e brasileiros que focalizam passagens da História de forte impacto coletivo e, por isso, capazes de produzir mudanças nas subjetividades. O recorte temático e conceitual se dará no eixo da História e da memória com foco no institucional e político, expressados desde o cotidiano e da experiência de indivíduos.

Nos filmes abordados personagens singulares interrogam o passado de maneira pessoal. A montagem ressignifica essas imagens no tempo presente e certifica esse recurso como uma das artes temporais que o documentário aperfeiçoou.

\section{Palavras-chave}

Documentários, história, memória, montagem.

\section{Abstract}

Starting from the articulation between the subjective and the public, which is common in documental productions, we aim to reflect on films that focus on moments of History with a strong collective impact, and, therefore, are capable of producing changes in subjectivities. The selections of films are related to the themes of History and Memory focusing on institutional practices and politics, expressed from the quotidian and from the experience of individuals.

In films that we address, singular personages interrogate the past in a personal way. The montage resignifies these images in the present time and certifies this feature as one as the temporal arts that documentary has perfected.

\section{Keywords}

Documentaries, history, memory, montage. 
Para Grierson, a afirmação de que o documentário é um 'púlpito' era um subterfúgio retórico. Que a essa alegação faltasse substância talvez não fosse sua culpa; ao contrário, era consequência da ampla tolerância da sociedade em que vivia para o debate, o que facilmente absorve toda crítica. Em outros lugares e outros tempos, circunstâncias mais repressivas conspiram para dotar o documentário de uma saliência na esfera pública que possui maior impacto. Na América Latina, com o militarismo do final do século XX arrefecido, o documentário se tornou menos um púlpito para proselitismo do que um divã de analista para cura do trauma social.

\section{Um mapa possível}

"América Latina" implica em muitas coisas, incluindo um imaginário continental. É um conceito - um pensamento que une políticas, culturas, linguagens e literaturas para construir uma comunidade imaginada e estabelecer um presente baseado em fundações comuns. Entretanto, não é fácil pensar em imagens e experiências que consigam sintetizar este continente. A tentativa de juntar a América Latina sob um único rótulo tinha uma raison d'être nas décadas de 1960 e 1970, quando havia uma base comum - uma busca comum de utopias. Hoje, essa base comum ainda existe, mas com modos heterogêneos de construção simbólica de uma comunidade e de conceber - ou nomear - tal integração.

A América Latina, como é conhecida, é também Ibero-América. O "Ibero-Americano" contém - entre muitas outras questões - uma assimetria linguística que se origina dos dois grandes poderes imperiais que há dois séculos dividiram o território do Novo Mundo: Espanha e Portugal. Processos de integração correntes estabeleceram parâmetros compartilhados em que as culturas se tocam tão de perto que é impossível pensar sobre a comunidade da América Latina de modo que exclua o Brasil. 
Assim, nossa intenção, primariamente, é demarcar nesse extenso mapa continental, a área que Brasil e Argentina partilham em termos geográficos e culturais. ${ }^{3}$ Porém, há diferenças que tornam difícil esta tarefa.

Uma primeira diferença jaz, precisamente, no volume da produção de documentários do Brasil. Este gênero, entretanto, tem se fortalecido nas duas últimas décadas - período chamado, em consequência, de "Primavera do documentário". Isto é o resultado de várias medidas institucionais que impulsionaram a produção, além do encorajamento proveniente da existência do É Tudo Verdade - Festival Internacional de Documentários. Desde sua primeira edição em São Paulo, em 1996, o É Tudo Verdade tem se repetido todos os anos, acontecendo nos estados de São Paulo e Rio de Janeiro, além de outros estados do Brasil. Não há dúvida de que este evento tem tido um grande impacto na recuperação da importância histórica do documentário, que pode ser claramente vista na emergência de novas tendências e novos espaços de exibição. Em 2001 o festival acrescentou as atividades da Conferência Internacional do Documentário, onde o documentário, em todas suas formas e variações, é considerado uma forma audiovisual fundamental. O resultado foi que o filme documentário se tornou um tópico principal de debate e reflexões, abrindo espaço para cada vez mais pesquisa, uma pesquisa mais e

3. Desde 1991 Brasil e Argentina fazem parte do MERCOSUL (Mercado Comum do Sul), juntamente com Paraguai, Uruguai e, ainda em processo de incorporação, Venezuela, Bolívia, Chile, Colômbia, Equador e Peru são nações associadas. Sua criação implicou em um grande número de inovações econômicas, sociais, políticas, culturais e simbólicas para as nações membro. Um ano chave foi 2003, quando a coalizão foi relançada pelos governos de Lula, no Brasil, e Kirchner na Argentina. Desde então, ocorreu um processo de fortalecimento da integração regional, para além das questões meramente comerciais, mas com um alargamento dos objetivos para outros grupos e com novas iniciativas em diversas áreas. Algumas das áreas que inicialmente não foram consideradas chave para a integração inicial, como a cinematografia (a indústria cinematográfica) entraram na agenda. A renovação do Mercosul é vista através da criação de uma organização específica, criada para discutir temas da indústria de cinema e audiovisual. A RECAM (Reunião Especializada de Autoridades Cinematográficas e Audiovisuais do Mercosul), com seus escritórios centrais em Montevidéu, Uruguai, desde 2003, é um corpo consultor de representantes das mais altas autoridades cinematográficas de cada nação participante. Entre 2003 e 2009, quando foi lançado o Programa Audiovisual do Mercosul, foram completados 37 filmes como coproduções que incluíam pelo menos duas nações-membro do Mercosul, na maioria dos casos, Brasil e Argentina. Para uma análise mais exaustiva das transformações do Mercosul em termos de cinema, ver: MOGUILLANSKY, Marina. Pantallas del sur. La integración cinematográfica en el Mercosur. 2011. Tese doutoral não publicada, Ciências Sociais, Universidade de Buenos Aires, Buenos Aires. 
mais generalizada e sistematizada. A característica particular deste movimento brasileiro de filme documental é que um fluxo contínuo de documentários é agora assistido em um número significativo de salas de cinema. Este é um fenômeno brasileiro que é claramente parte de um contexto internacional, mas com suas próprias características, particularmente dentro do continente. ${ }^{4}$

A diversidade cultural do Brasil está expressa na diversidade de tópicos e estéticas de cada uma de suas regiões. A Argentina não possui uma produção tão regionalmente definida. Entretanto, repetindo o movimento "excêntrico" do continente - a "excentricidade" sendo, atualmente, central - e especialmente devido à nova Lei da mídia audiovisual ${ }^{5}$, a produção de filmes em todo o país se expandiu de forma significativa, oferecendo à televisão local importante quantidade de produções independentes. A abertura da mídia e o surgimento de espaços de exibição alternativos permitiu a circulação de vozes e temas que são notavelmente diversos. Isto alimentou uma busca constante por novas formas de expressão documental.

\section{Um ponto de partida e dois eixos}

Para estabelecer os limites necessários para o escopo de nosso estudo dessa diversidade e experimentação, nós identificamos certos eixos. Estes eixos não servirão para canonizarmos trabalhos ou autores. Ao contrário, iremos examinar aqueles filmes que, tomados como um todo, nos permitem esboçar um mapa preliminar das questões levantadas em geral pelo encontro

4. Em 1996 apenas um documentário de longa metragem foi exibido nos cinemas - Todos os corações do mundo (Murilo Salles, 1995). Em 2006 foram vinte e seis e em 2010, vinte e quatro. Outro detalhe interessante é que em 2011, no Brasil, foram produzidos sessenta filmes documentários, contra cinquenta e nove de ficção.

5. A Lei 26.522 dos Serviços de Comunicação Audiovisual governa a operação das mídias de televisão e rádio na Argentina. Promulgada em outubro de 2009 pela presidenta Cristina Kirchner, veio substituir a regulação estabelecida pela ditadura militar em 1980, que limitava a liberdade de expressão, bem como a propriedade dos meios a certas empresas. Abrindo espaço para novas permissões/licenças e espaços, esta lei estimulou uma intensa produção audiovisual, com forte ênfase no uso do documentário por parte de entidades educacionais, sociais e outras organizações similares através de todo o país. 
(ou choque) do subjetivo e do público - uma articulação comum, afinal, na produção contemporânea mundial de documentários. Tal articulação é claramente atravessada em nosso mapa por um par de eixos particularmente salientes, temáticos e ao mesmo tempo conceituais: isto é, história e memória.

Entendemos a história não como uma programação estreita que conecta o coletivo institucionalmente, mas também em um sentido mais amplo. Estamos interessadas naquela história construída a partir da experiência cotidiana daqueles que a vivem em diferentes estágios de suas vidas e a transformam em suas próprias histórias. Precisamente no cruzamento entre vidas públicas e privadas, em como as subjetividades se relacionam com o mundo, fazendo uma ponte entre o passado e o presente. Isto, então, permite que a memória tente organizar o caos da história dentro dos limites de um documentário biográfico ou autobiográfico.

As questões que servem como ponto de partida a nos guiar nesse ter reno envolvem não apenas estas questões como tópicos, mas também incluem os dispositivos formais que os documentários por nós selecionados empregam para tratar dessas questões. Como são organizadas as imagens, sons, fotos, documentos, declarações orais e escritas para tocar o passado quando essa história é recordada no presente? Qual é o tratamento apropriado para o material audiovisual e textual de modo a trazer para o presente o seu verdadeiro conteúdo histórico?

Em termos tradicionais a tendência é propor o filme documentário como ilustração e reflexão sobre este ou aquele período da história. O objeto de ilustração ou reflexão é entendido como um "evento" (um termo que, acreditamos, gera tantas definições quanto existem intérpretes). Mas preferimos reduzir "evento" ao seu significado mais imediato: fatos que criam processos frequentemente imprevisíveis e que produzem um forte impacto coletivo. Esses "fatos" sobre "eventos" são capazes, por esta razão, de produzir mudanças importantes no entendimento. Repetidamente, o instrumento usado para se fazer isto com o documentário é recorrer a imagens de arquivo com a inscrição distintiva do papel autoral (por 
ano 2 número 4

Dossiê

exemplo, na edição ou montagem). Isto define a estrutura formal do documentário ibero-americano quando o tema é a história coletiva. ${ }^{6}$

No Brasil, os documentários de Silvio Tendler revisam o período pré-ditatorial de sua história do século XX através das biografias fílmicas de uma série de líderes democráticos falhos. Os anos JK - uma trajetória política (1980, Brasil) narra a história da ascensão política de Juscelino Kubitschek. Para ilustrar seu período presidencial (1955-1960), Tendler enfatiza a audácia de construir Brasília, a nova capital bem no coração geográfico do país, e o final trágico do homem. Os direitos políticos de Kubitschek foram eventualmente retirados pelo governo militar, e na sequência ele morre em um acidente de carro. Em 1981 o diretor Luis Alberto Pereira dirigiu o documentário Jânio a 24 quadros, sobre o curto período presidencial de Jânio Quadros, que sucedeu Kubitschek e renunciou em agosto de 1961, após governar por oito meses. Ele foi sucedido por João Goulart, o sujeito do documentário seguinte na filmografia de Tendler: Jango (1983, Brasil). Goulart foi o último presidente democrático, derrubado pelo golpe militar de 1964. Em Tancredo, a travessia (2010, Brasil), Tendler dá seguimento à documentação fílmica da presidência do Brasil com o estudo da carreira política de Tancredo Neves, o primeiro presidente civil depois das duas décadas de ditadura militar. Tancredo foi indicado em 1985 como resultado do acordo entre os militares e os partidos políticos durante a transição entre a ditadura e a volta à democracia, mas veio a falecer de repente, jamais tendo assumido o cargo.

O documentário também foi o veículo cada vez mais escolhido durante os anos 1990 na Argentina para estudar eventos do passado histórico e do presente social, eventualmente se transformando num dos mais importantes gêneros cinematográficos da produção fílmica argentina no início deste novo século.

6. No Brasil, a ditadura militar governou entre 1964 e 1985. Foi o período mais longo de uma ditadura e o modelo se espalhou por toda a América Latina durante a década de 1970. No Chile, a ditadura militar governou durante o período 1973-1984 e na Argentina entre 1976 e 1983. A relação entre o cinema e a memória constituiu um dos temas mais explorados no filme documentário da América Latina, embora o tema assumisse diferentes perspectivas formais e precedentes históricos, considerando que a Argentina e o Brasil - assim como o Chile - seguiram estilos e caminhos diferentes em seu retorno à democracia. 
Uma parte substancial do cinema argentino atual usa o documentário e expressões poéticas complexas para construir relatos de memória individual e coletiva, bem como para dar testemunho às consequências dos crimes de genocídio da ditadura naquele país que, entre 1976 e 1983, destruiu milhares de vidas, uma geração de jovens. A revisão desses crimes teve um aspecto de pesquisa e denúncia durante o primeiro período da volta à democracia. Por exemplo, em Juan, como si nada hubiera sucedido (1987, Argentina), Carlos Echeverría, o realizador, documentou em termos formalistas e temáticos, a investigação do sequestro e desaparecimento de um estudante universitário e ativista da esquerda peronista na cidade de Bariloche durante a ditadura militar.

Entre outros recursos visuais e narrativos empregados por Echeverría, a história é contada na primeira pessoa, com um ator representando o diretor, enquanto a narrativa ilustra cada estágio de sua investigação. Esta abordagem forneceu um modelo que exerceu notável influência sobre trabalhos posteriores no gênero.

Durante os anos 1990, o foco também foi em documentários sobre organizações revolucionárias. Mais uma vez, a técnica do testemunho predomina. Em Montoneros, una historia (1994, Argentina), dirigido por Andrés Di Tella, as ações dos ativistas militantes pertencentes ao grupo armado Montoneros, e a violência repressiva desencadeada contra eles são relatados por diferentes grupos políticos. O filme é estruturado em torno das memórias de um protagonista, um sobrevivente de um centro clandestino de detenção. Um ano depois deste filme, Cazadores de utopias (1995, Argentina), dirigido por David Blaustein, apresentava outros testemunhos de antigos militantes montoneros. Esses testemunhos são contados de maneira altamente subjetiva, com as histórias individuais montadas para oferecer um relato coral da memória histórica e política.

Desde o começo deste milênio tem havido, notavelmente, uma significativa produção de filmes documentários realizados pelos filhos das vítimas desta geração dos anos 1970. Cada filme exibe maneiras diferentes, diretas ou indiretas, de rever as ações e discurso político de seus pais. Papá Ivan (2000, Argentina-México), dirigido por María Inés Roqué, e Los rubios (Argentina, 2003) são filmes canonizados devido à força de suas buscas pela verdade de 
ano 2 número 4

Dossiê

seus pais. Eles demonstram vividamente o uso do documentário como um instrumento da memória e da identidade pessoal, além de prestar homenagem às vítimas da opressão extrema. No contexto contemporâneo, afirmam a diferença geracional, mas, ao mesmo tempo, mostram respeito. Muitos filmes assim foram realizados - por exemplo, mais recentemente $(H)$ Historias cotidianas, primeiro documentário de Andrés Habergger (2001, Argentina), e M (2008, Argentina), de Nicolás Prividera entre outros.

No Brasil, este tropo é também um desenvolvimento recente do século XXI. Muito embora existam alguns filmes de ficção que lidam com o período ditatorial, não foi até os anos 2000 que emergiu uma concentração de documentários de longametragem tratando diretamente do período militar. Sem dúvida, esse crescimento é uma consequência da criação da Comissão Especial em 1995 - dentro da Secretaria de Direitos Humanos do Brasil, que em 2003 ganhou status de Ministério - para investigar os “desaparecidos" brasileiros durante o período militar.7

Neste grupo de filmes temos Cidadão Boilesen (2005, Brasil), dirigido por Chaim Litewsky, sobre a execução de um homem de negócios - Boilesen, o cidadão do título - por um grupo guerrilheiro armado, a quem acusam de financiar a clandestina Operação Bandeirantes (OBAN). Ele era acusado de cumplicidade direta nas torturas selvagens praticadas pela organização. Em Hércules 56 (2006, Brasil), Silvio Da Rin conta a história de um dos momentos mais tensos durante a ditadura: o sequestro, em 1969, do embaixador americano Charles Elbrick como refém a ser trocado por quinze prisioneiros políticos. Estes foram libertados e voaram até o México num avião Hércules 56 - daí o título do filme. Cinco dos sequestradores são filmados sentados em torno de uma mesa enquanto relembram detalhes do evento e do contexto político que os motivou. Seus comentários são alternados com testemunhos de outras pessoas e imagens de arquivo.

Em Caparaó (2007, Brasil) Flávio Frederico enfoca a primeira tentativa de luta armada contra o regime militar. Conta a história de uma revolta contra o governo,

7. Em 2011, sob a presidência de Dilma Rousseff, foi criada a Comissão Nacional da Verdade para investigar as violações dos direitos humanos durante o período 1946-1988. 
em agosto de 1966, por um grupo de ex-soldados dispensados de unidades do exército estacionadas na Serra do Caparaó. Operação condor (2007, Brasil), dirigido por Roberto Mader, investiga a cooperação através das fronteiras entre agências de inteligência de diferentes governos militares da América do Sul e suas práticas de sequestro e assassinato de militantes e ativistas políticos.

Excesso de testemunhos - cabeças falantes como principal fonte de informação - que fazem da palavra o fundamento do significado e condicionam as narrativas, são repetidamente empregados nos documentários que mencionamos. Isto pode ser entendido como algo que ocorre à custa de técnicas mais criativas, em que se poderia dar mais relevância para, por exemplo, o texto - escritura - e sua relação, reconciliada ou não, com a imagem. Mas nem todos concordariam com a condenação do uso extensivo do testemunho de "cabeças falantes" como tendo eficácia limitada em termos fílmicos. Agnès Varda, por exemplo, acredita que "o preconceito acadêmico de que um documentário não pode ser uma mera sucessão de testemunhos (fez com que) fosse todo vestido e inflado com uma profusão de recursos irrelevantes". 8

É essencial mencionar aqui o chileno Patrício Guzmán, cujos documentários demonstram perfeitamente a passagem entre memória e história. O canônico La batalla de Chile (1972-79, Chile-França) oferece um relato excepcional sobre as alternativas políticas, sociais e culturais que estavam sendo implementadas pelo governo de Salvador Allende. Estas se desenvolvem no presente, criando um arco narrativo que conduz, inexoravelmente, ao golpe militar e à queda de Allende em 1973. Em La memória obstinada (1997, Chile), Guzmán retorna a esses eventos usando o testemunho de muitas das pessoas envolvidas. O papel de vozes e imagens de sobreviventes e de outras testemunhas é igualmente central em seu Pinochet (Chile, 2001), e em Allende (2004, Chile).

Seu recente Nostalgia de la luz (2010, Chile) explora de modo brilhante múltiplos níveis de metáforas para a ausência. Trata-se de uma observação filosófica sobre a memória, o tempo e o cosmos sob o céu claro do deserto do Atacama, onde os antigos deixaram milhares de geoglifos (seus significados 
ano 2 número 4

Dossiê

em boa parte perdidos), enquanto os astrônomos modernos examinam os céus como os parentes dos desaparecidos escavam covas coletivas onde jazem os restos das vítimas da ditadura.

As representações das mortes e dos massacres não são significadas em documentários somente por meio do testemunho oral, embora este predomine; às vezes, técnicas explorando as relações entre textos e formas visíveis são também usadas para ilustrar o que, de outra maneira, não poderia ser representado. Trelew: La fuga que fue massacre (2004, Argentina), dirigido por Mariana Arruti, apresenta uma detalhada reconstrução através do testemunho de sobreviventes. A atrocidade, o assassinato a sangue frio de dezenove guerrilheiros presos na base naval de Trelew, nas costas da Patagônia, são relembrados sem o uso de imagens, já que a narrativa oral (ou verbal) descreve a cena da execução.

Em La imagen final (2008, Argentina), de Andrés Habegger, a imagem que falta é aquela da morte do câmera Leonardo Henriksen. Henriksen filmou seu assassino, o soldado que vemos atirando contra ele durante o assalto ao Palacio de la Moneda em 1973.

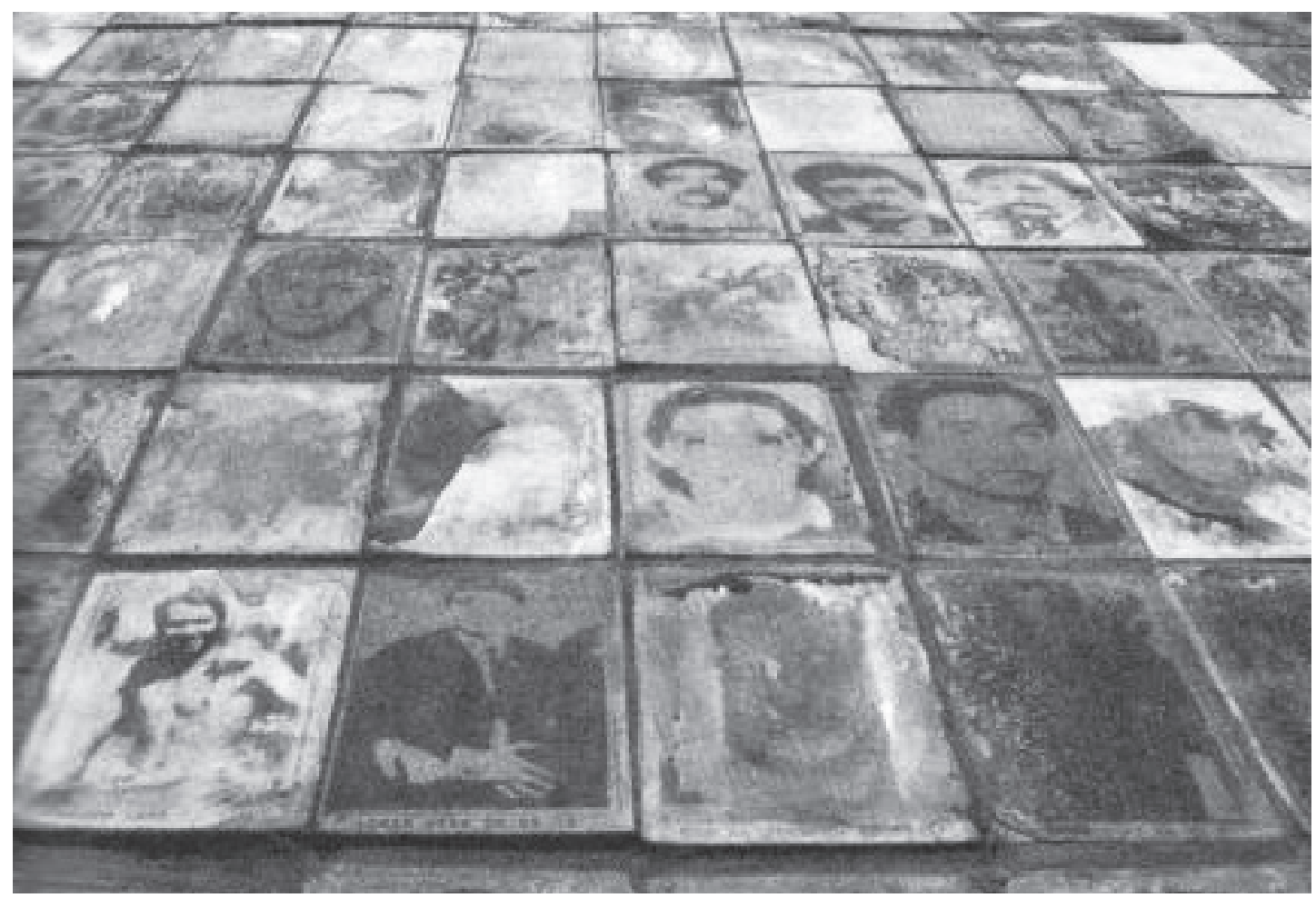

Nostalgia de la luz (2010): uma observação filosófica sobre a memória, o tempo e o cosmos sob o céu claro do deserto de Atacama. 
Em El predio (2010, Argentina), de Jonathan Perel, o que falta é o contrário: palavras - testemunho. Por esta razão, o poder do visual é o único modo que resta para transmitir o hor ror da Escola Mecânica Naval (ESMA), o maior centro de tortura e desaparecimento durante a ditadura. Em Pacto de silencio (2005, Argentina) Carlos Echeverría estabelece a verdade sobre o presente através da exibição sem remorsos de arquivos que visualmente evidenciam a cumplicidade dos moradores de Bariloche na defesa do assassino nazista Erich Priebke, que se escondia alegremente entre eles havia décadas.

\section{período das "images-vérité/imagens-verdade"}

Durante os anos 1960, havia no Brasil e na Argentina o desejo de entender "o povo": através do documentário, a história social entra em cena. Fernando Birri, com Tire dié (1960, Argentina) e Los inundados (1962, Argentina), teve uma profunda influência por todo o continente com sua estética neorrealista. Usando este precedente (e com tópicos também tocados nos filmes de ficção do Cinema Novo), o documentário brasileiro abordou temas sociais e políticos contemporâneos. Viramundo (1965, Brasil), de Geraldo Sarno, considerado pelo crítico brasileiro Jean Claude Bernadet "um clássico do documentário social brasileiro", acompanha camponeses no Nordeste do Brasil fugindo da seca somente para sofrer a proletarização em São Paulo. A narração enfatiza neste deslocamento o papel do misticismo e da religiosidade para aliviar as condições de pobreza, inadequação social e dificuldades de integração dos migrantes. O ambiente urbano de classes heterogêneas em São Paulo também é o cenário para Liberdade de imprensa (1967, Brasil), de João Batista de Andrade, um documentário provocativo em estilo cinéma vérité, realizado no meio da ditadura. Andrade dá início a discussões nas ruas do centro de São Paulo sobre o amordaçamento da imprensa pelas autoridades. Com este filme começa o movimento do "Street cinema", caracterizado pela estratégia de intervenção direta do cineasta. Ele dá importância às vozes excluídas, corrigindo a negação do debate público. Em Opinião pública (1967, Brasil), de Arnaldo Jabor, o foco do documentário, também no estilo cinéma vérité, é a classe média brasileira, 
ano 2 número 4

Dossiê

especialmente os grupos conservadores no Rio de Janeiro e sua cumplicidade com o golpe militar de 1964.

Filmes do grupo Cine Liberación, por exemplo, El camino hacia la muerte del viejo Reales (1968, Argentina), dirigido por Gerardo Vallejo, enfatizam os símbolos da pobreza humana e material como um chamado à ação num sentido abertamente político. La hora de los hornos (1968-70, Argentina), de Fernando Solanas e Octavio Getino, também do grupo Cine Liberación, é um documentário que une formalmente as avant-gardes políticas e artísticas, ao ponto de ser precedido e acompanhado por declarações que ressaltam a intenção de usar o filme como instrumento de inter venção e de agitação política direta. Através de sua distribuição nacional e internacional arriscada (porque proibida), este filme canônico se tornou o maior exemplo de cinema político engagé produzido na América Latina (ao menos, é o que dizem alguns) durante os anos 1970.

Seguindo uma tendência internacional, a produção da década de 1970 no Brasil se tornou mais diversificada. Um espectro mais amplo de tópicos foi abordado. Foram produzidos documentários experimentais e reflexivos, como Congo (1972, Brasil), em que Arthur Omar documenta um ritual folclórico recorrendo a procedimentos visuais que rompem com a tradição do documentário etnográfico. Di (1977, Brasil), de Glauber Rocha, pode ser referido como um documentário registrando um evento (o funeral de um dos mais importantes pintores brasileiros, Di Cavalcanti); mas também envolve intervenção direta na ação. Esta mistura de cinéma vérité e a estética da reportagem de televisão ao vivo promovem um estilo que Glauber desenvolveria mais tarde em seu programa de televisão Abertura, entre 1979 e 1980.

Durante este período, os realizadores no Brasil começaram a produzir filmes que exploravam a fronteira entre documentário e ficção, antecipando o traço mais óbvio do realismo, tal como hoje é visto no cinema atual. Jorge Bodansky e Orlando Senna já nos haviam feito confrontar o choque documentário/ficção com Iracema, uma transa amazônica terminado e censurado em 1975. Os líderes militares no poder de então tinham desenvolvido uma política de integração e desenvolvimento nacional que incluía uma rodovia através da Amazônia legal. O filme ataca o projeto ao documentar a destruição da região, o uso 
de trabalho escravo e a difusão da prostituição. Faz isto no contexto de uma história ficcional, de Iracema, uma garota da região. (Iracema é enganada por um caminhoneiro, Tião Brasil Grande, e termina como prostituta nas margens da rodovia Transamazônica.)

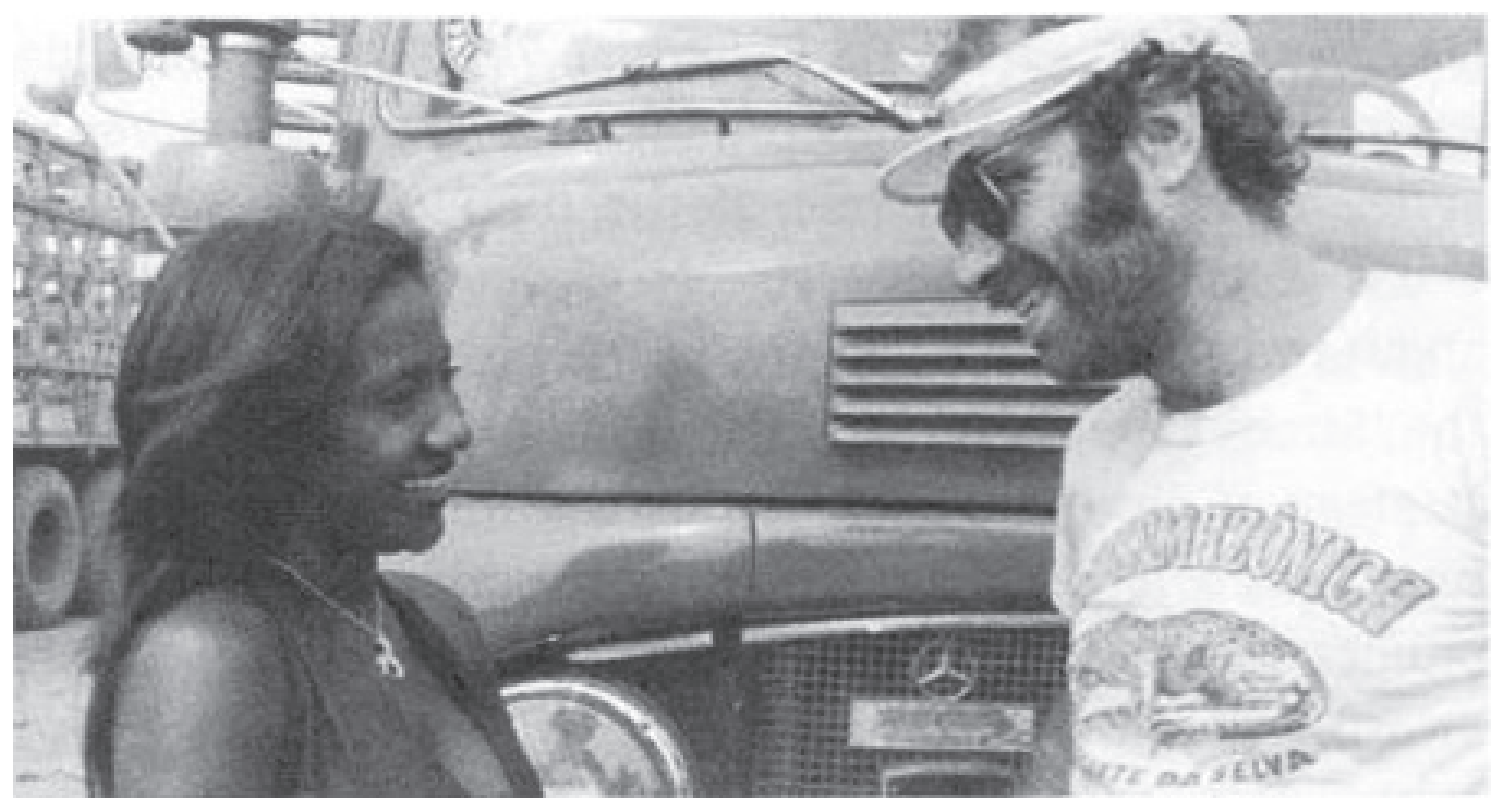

Iracema, uma transa amazônica (1975): fronteira entre documentário e ficção.

O filme contemporâneo que ecoa Iracema é Serras da desordem (2006, Brasil), de Andrea Tonacci. Este documentário também se concentra num personagem principal, um índio chamado Carapiru, mas introduz um aspecto ficcional quando Tonacci convida Carapiru a reconstruir sua própria história. O próprio Carapiru reencena, como um ator, sua história de aculturação forçada que, assim como no caso de "Iracema", reflete a política civilizadora da nação brasileira. Ele retornou para a floresta onde vivia e traça novamente sua vida ali; mas quando Carapiru recorda e reconstrói sua história, ele se aproxima da narrativa ficcional.

Então, o ambiente é real, a história é real, e o tópico é o mesmo de Iracema - problemas do desmatamento devidos ao avanço da "civilização", causando transformações sociais e culturais drásticas. O filme avança com fragmentos e oposições (indivíduo e sociedade, natureza e civilização, ficção e realidade), tornando difícil para a plateia se sentir confortável. Isto é exacerbado com uma notável experimentação com a linguagem. 
ano 2 número 4

Dossiê

Durante os anos 1980 se observa um movimento em direção ao ensaístico, com documentários muito críticos, irônicos e conceituais. Mato eles? (1982, Brasil), de Sergio Bianchi denuncia a apropriação ilegal de terras indígenas no sul do Brasil, enquanto Ilha das flores (1985, Brasil), de Jorge Furtado, condena a pobreza, a fome e a exclusão social. São exemplos de documentários que tratam de problemas sociais, mas que subvertem a hegemonia da abordagem clássica ao rejeitarem a apresentação de uma tese (sociológica, filosófica, ou simplesmente poética) como determinante da estrutura do filme.

Iconografia, alegoria, mitos e história

Para atravessar a história escura e o drama da Argentina na segunda metade do século XX, a linguagem do mito pareceu ser uma boa aliada. Em ambos os aspectos, narrativo e visual, Pulqui, Un instante de la patria de la felicidad (2006, Argentina), dirigido por Alejandro Fernandez Moujan, incorpora esse aspecto mítico da história. A inesgotável iconografia do primeiro período do peronismo inspirou o artista visual Daniel Santoro a recriar em sua tela momentos chave do imaginário coletivo, sintetizado nas figuras de Perón e Evita; cenas de bemestar doméstico, arquitetura pública e as ruínas do passado de felicidade. Dentre estas imagens que ele pinta está aquela de um pequeno avião, o "Pulqui", um feito emblemático de engenharia representando a perícia do peronismo. A construção de uma reprodução em escala do avião inspira Moujan, que documenta os estágios da reconstrução até sua efêmera tentativa de voar.

Julián d'Angiolillo, em Hacerme feriante (2010, Argentina), trata de outro mito, aquele do período feliz de lazer durante o primeiro período peronista. O filme enfoca La Salada - originalmente construído nos anos 1950 como parque e resort nos subúrbios de Buenos Aires - tomando como ponto de partida a emblemática transformação do espaço em um mercado de pulgas noturno gigantesco, informal, densamente ocupado. Com o uso de freeze-frames d'Angiolillo ilumina pontos do passado, trazendo-os para o presente, buscando aquelas imagens e linguagens por um pouco da intensidade original dos momentos dos quais já não existe mais registro. Este é um modo positivo de se trabalhar com mitos, criando uma forte 
dialética, necessária para se entender o presente. Em suas notas documentais, Pasolini disse que nenhum presente poderia ser construído sem se apelar para a história mítica, uma espécie de inconsciente coletivo como cimento indispensável para o contemporâneo. ${ }^{9}$

Leonardo Favio seguiu esse princípio, transformando a linguagem do mito na base da articulação visual e narrativa de seu longo documentário Perón, sinfonía del sentimiento (1996-2000). Ali ele dá um tratamento ficcional a imagens de arquivo e outras fontes documentais (slides e som de arquivo) ao inter-relacionálos com a história. O filme se autoanuncia como um documentário e, de fato, Favio oferece um documentário histórico do peronismo. O traço mais importante da estrutura narrativa, porém, é o uso da linguagem do mito; isto é, o relato complexo que emerge da fusão de passado e presente (um tempo "back/forward"). Isto cria imagens míticas dos fatos históricos. Favio lança mão de vários recursos para manipular imagens e som, como a reconstituição de material de arquivo, para reforçar a representação visual, a utilização de atores que são sósias de Perón e Eva, além de outros sósias para os líderes políticos e sindicais que os rodeavam. Todo esse material está ligado (de novo) aos desenhos e pinturas de Daniel Santoro, que enfocam temas e personagens peronistas. O resultado é uma visão quase 'sacramental' do passado peronista, narrado de um modo plausível e crível para perpetuar a história.

Isto transforma o mito numa máquina narrativa da história; mas há aqueles que associam essa técnica à propaganda, criando sentimentos exagerados ao repetir cenas "populistas". Paradoxalmente, o fato de a atenção ser dirigida para isto acaba realçando uma marca (ou uma espécie de peculiaridade expressiva) que é imputada ao nosso cinema, à América Latina em geral e, por extensão, a todos os países do "Terceiro Mundo". Os artistas neste universo estão de algum modo condenados a narrar a história sempre como crise, catástrofe e miséria.

9. Pasolini, em uma das sequências mais interessantes de seu documentário Appunti per un'orestiade africana (1970), afirma enfaticamente que: "Os mitos dos ancestrais devem coexistir com sua democracia recuperada". Estudantes africanos, ouvindo-o numa universidade de Roma, rejeitaram seus argumentos com a mesma força. 
ano 2 número 4

Dossiê

Nos anos 1980 Fredric Jameson cunhou o conceito de "alegoria nacional" - que tem gozado de uma longa vida, a despeito das críticas recebidas - para definir o cinema e a literatura desses países que, diferentemente dos sistemas hegemônicos de representação, tendem a contar histórias individuais como uma alegor ia para situações públicas. Jameson exemplifica isto com sua inter pretação dos filmes de Solanas e Ousmane Sembène, entre outros. ${ }^{10}$

Um documentário que deve ser considerado quando se trata da revisão do passado histórico é Cándido López: Los campos de batalla (2005, Argentina), dirigido por José Luis García. O filme não lança mão de mitos ou alegorias, mas das artes visuais, já que o guia conceitual e visual para sua narrativa é uma série de pinturas a óleo de Cándido López (1840-1902). Cándido López foi soldado e jornalista durante a Guerra da Tríplice Aliança (1865-70), declarada por Brasil, Uruguai e Argentina contra o Paraguai. O diretor, que também se torna o narrador do filme, começa sua jornada através da Argentina e Mesopotâmia Brasileira, andando pelos campos de batalha (onde estilhaços de granada ainda podem ser vistos), e reproduzindo com sua câmera o famoso "ponto de vista alto" usado por Cándido López. Esta era uma técnica bastante cinemática, retratando as cenas de batalha, como se mostrasse, num plano geral do alto, ações múltiplas e simultâneas. Na estrada, o diretor descobre histórias pessoais e, ao mesmo tempo, as razões por que esses estados ocultaram essa guerra de extermínio lançada contra o Paraguai.

Gilles Deleuze analisou o trabalho de autores "marginais", talvez com mais sutileza do que Jameson, assimilando a ideia postulada por Kafka sobre a força potencial, mas subversiva, da "literatura menor" produzida nos pequenos países da Europa Central. Tal força pode ser atribuída a mitos que atravessam a fronteira que separa questões políticas e privadas - por exemplo, nos filmes de Glauber Rocha. ${ }^{11} \mathrm{O}$ ponto de vista que garante uma ponte seria a subjetividade - a pressuposição do direito do indivíduo de interrogar o mundo em um exercício

10. Fredric Jameson, "Transformaciones en la imagen en la posmodernidad" [Transformations in the image in postmodernity] Revista de Crítica Cultural n. 6, ed. Cuarto Propio (Santiago de Chile: Marzo 1993). Tradução de "Third world literature in the era of multinational capitalism", Social text n. 5, Autumn 1998. 
de invocação de memórias que não são nem completamente pessoalmente psicológicas, nem completamente coletivas, mas uma rua de mão dupla entre o pessoal e o público.

\section{Poéticas da experiência e documentos da memória}

O gênero documentário se alargou e abriu espaço para novas formas de expressão que, em um movimento panorâmico e circular, dá espaço para novas formas de representação e enunciação. A tradição clássica de observar e/ou ref letir sobre o "outro" foi rompida quando houve a incorporação do "eu" pela primeira vez. O documentário da América Latina começou a buscar um lugar para o sujeito na representação do mundo. Uma nova forma de construir a subjetividade no documentário contemporâneo emergiu, operando principalmente através da criação de conexões sentimentais entre o realizador e o público, conexões que um cinema subjetivo sempre procura construir.

Narração subjetiva e imagens pessoais documentais permitem explorar a relação entre assistir e relembrar. E é nesta relação que se configura um discurso interior para revelar a verdade do artista; e, ao mesmo tempo, as imagens também mostram alguma verdade sobre o mundo, ou sobre algum estágio da história. Essa busca pela identidade no mundo tende para a globalização. É um movimento que busca transformar um discurso interno em um discurso manifesto em que o pessoal e o subjetivo são predominantes. A primeira pessoa adquiriu importância expressiva política e cultural durante as décadas recentes; então, é importante determinar o "lugar do sujeito" na representação do mundo levada a cabo pelo documentário.

João Moreira Salles, em Santiago (2006, Brasil), quer contar a história de Santiago, o mordomo da família. Entretanto, sua atuação pessoal como diretor e entrevistador reestrutura tanto o discurso que o filme - que deveria ser sobre a fascinante personalidade de Santiago, um pesquisador obsessivo e quase delirante de dinastias e aristocracias do passado ao redor do mundo - se transforma mais em uma história da relação entre ele e Salles, entre 
ano 2 número 4

Dossiê

mordomo e patrão, transformando o foco do filme. Ao invés do retrato do serviçal, torna-se revelador de uma relação de poder, expondo a identidade do patrão, o diretor do filme.

Isto se dá em boa medida graças aos diferentes estágios da dinâmica de produção do filme; Salles começou a filmar Santiago em 1992, mas abandonou o projeto na fase de montagem. Em 2005, quando retomou o trabalho, Santiago havia morrido. Ao processar as imagens treze anos mais tarde, Salles notou como elas mostravam mais a história dele e de sua família (as tradições da classe alta, o pai diplomata, a mãe, os irmãos, ambientes luxuosos, jantares de negócios, grandes festas, etc.) do que a de Santiago. O narrador é um de seus irmãos que, lendo um texto escrito por João, sobrepõe a primeira pessoa sobre ambos. O filme se transforma na memória partilhada de uma casa e um mundo que não existem mais.

Cabra marcado para morrer (1964-84, Brasil), de Eduardo Coutinho, também trilha diferentes períodos de tempo através de seus processos de produção. As filmagens começaram em 1964 com a reconstrução da história do assassinato de um líder camponês, usando atores que são eles próprios camponeses. O golpe militar interrompeu a produção, que foi retomada em 1981, quando Coutinho retornou ao local e encontrou seus atores principais do passado. Coutinho é um dos mais notáveis documentaristas contemporâneos em sua exploração dos limites da verdade expostos pelas falhas e diferenças entre testemunhos, memórias.

Em Cabra marcado para morrer, os conflitos entre os diferentes "eus" que testemunham e revelam uma história realmente chocante em que o pessoal está inexoravelmente ligado à história política e social do país.

Jogo de cena (2006, Brasil) talvez seja o filme em que ele mais joga com essas questões. Através de um anúncio de jornal, ele solicitou histórias de vida de mulheres como base para seu roteiro, que ele então filmou usando atrizes que recontavam essas histórias em um palco de um teatro do Rio. Coutinho cria assim uma relação entre as informantes, as atrizes sentadas no palco e ele mesmo. A cena teatral inclui Coutinho, sua equipe e o equipamento. Ele se faz presente, tornando-se, poderíamos dizer, o narrador de si mesmo. 
Dentre os filmes mais recentes de Andrés Di Tella, aqueles que ele realizou neste século, há vários no registro que dão ressonância literal à voz ao dissecar a subjetividade da primeira pessoa. Di Tella investiga a memória e a intimidade consciente e inconsciente.

A começar por La televisión y yo (2003, Argentina), onde isto é enfatizado no próprio título, e no qual Di Tella usa um estilo que difere daquele usado pelos brasileiros. Este primeiro filme retoma o fato histórico de que sua família era dona da companhia que produzia tudo, de refrigeradores a automóveis para a próspera Argentina do primeiro período do peronismo. Neste filme, com a mediação de uma figura paterna, ele revive a memória da família e uma linhagem ao mesmo tempo histórica e política.

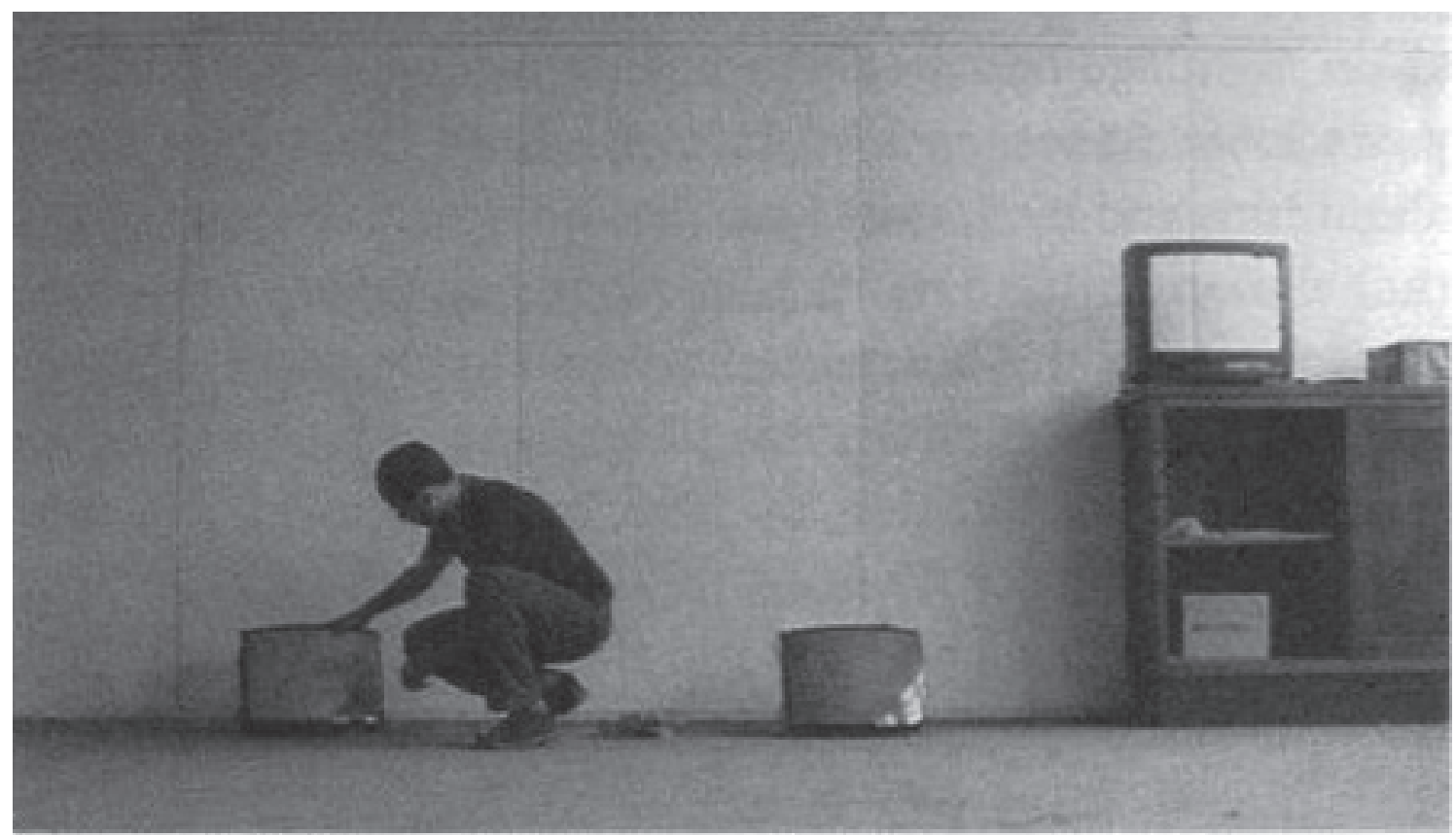

La televisión y yo (2003): memória familiar e linhagem histórica e política.

Em Fotografias (2007, Argentina), a evocação de sua falecida mãe - uma psicanalista indiana que teve uma carreira notável na Argentina na década de 1960 - cria novamente um fluxo narrativo entre o privado e o coletivo. Na sequência desta linha, algumas noções sustentadas pela história institucional e oficial acabam sendo alteradas por achados inesperados do documentário.

Voz, linguagem, o arquivo (o material da história), junto com as sequências contingentes à memória, tudo isso é parte do repertório usado por aqueles que partilham a condição de realizadores profissionais com a condição de serem 
ano 2 número 4

Dossiê

filhos dos desaparecidos (Albertina Carri, María Inés Roqué, Nicolás Prividera, dentre outros). Em seu trabalho, eles usam as relações formais entre documento e ficção, intimidade e personagem.

A voz do "eu" como uma ponte entre o tempo histórico e pessoal é apresentada de modo mais significativo em Los rubios de Albertina Carri, que documenta como o luto privado e o exercício pessoal da memória entram em contato com a história argentina em seu ponto mais violento.

De modo alternativo, a dissociação entre voz e imagem pode ser vista em Apuntes para una biografia imaginaria (Edgardo Cozarinsky, 2010, Argentina). Cozarinsky cria uma tensão formal e visual entre o subjetivo e o objetivo, o factual e o recriado - em resumo, entre "o que foi vivido e o que foi filmado". Portanto, este pode ser descrito como um "documentário imaginário" (ecoando o título de Cozarinsky).

Sua prática justifica o oximoro porque o caráter "realista" do material do filme - material de arquivo cobrindo vários episódios da segunda guerra europeia, ou várias referências históricas na Argentina - é marcado subjetivamente pela adição de referências pessoais à imagem e no voice-over. A "verdade" desses fatos da história coletiva ou pessoal é ilustrada, assim, pela abundância de material de arquivo.

Neste e em outros documentários mencionados, discurso e subjetividade expressam a memória como um imaginário. São as ferramentas com que corpo, voz e o arquivo de imagens criam uma política de significação. Um elemento de indecisão resulta que, de alguma maneira, define um novo modo de realismo, um realismo digno do comentário de Deleuze, que o distingue como uma qualidade do cinema "periférico":

O oposto da ficção não é o real, não é a verdade, que é sempre aquela dos mestres ou dos colonizadores; mas, ao contrário, a fabulação dos pobres, naquilo em que atribui ao falso o poder que o transforma numa memória, uma lenda, um monstro. ${ }^{12}$ 
Em Apuntes os arquivos de imagem de Cozarinsky e os arquivos de outros são os instrumentos com que, na montagem, ele ressalta o anacronismo. Ele não fez isso quando seguiu o caminho cronológico de seus ensaios biográficos anteriores (La guerra de un solo hombre (1981); Scarlati on Sevilla (1990); Bulevares del crepúsculo (1992); Citizen Langois (1994); Fantasma de Tánger (1997). Porém, em Apuntes, Cozarinsky é o objeto de seus próprios questionamentos; ele segue autobiograficamente a caprichosa meada de imagens que atestam - através da cumplicidade verbal, ou simplesmente visual - as memórias e experiências em que o self e o "outro" possuem o poder deleuziano que faz com que o falso impulsione a memória ou a lenda.

De uma geração de realizadores para outra, uma memória comum libera imaginários complementares. Em Apuntes e no curta-metragem de Albertina Carri, Restos (2010), um desaparecimento de segundo grau é experimentado quando as imagens são gravadas por cineastas e outros que, eles próprios, desapareceram nos anos violentos da ditadura. Os filmes que eles deixaram constituem uma espécie de arquivo fantasma. Filmes também “desapareceram”. Originalmente clandestinos, foram confiscados pelas autoridades e sumiram sem deixar traço - nem mesmo de sua ausência.

A “memória daquilo que sobrou” é como Cozarinsky descreve o destino do celuloide que "desaparece" desse jeito para ser reciclado em nível industrial e transformado em roupas, escovas, cabelo, graxa de sapatos (objetos que são todos metonímias para o corpo). Uma tomada memorável de Restos nos diz que não há volta; o celuloide não é reciclado, é dissolvido, com um literalismo que é quase orgânico, em ácido: metonímia dos corpos e seu desaparecimento.

\section{Do mito para as fábulas contemporâneas}

Antes, a dramaturgia por trás do documentário era a síntese, a capacidade de um personagem para simbolizar um grupo, uma classe. Esse contexto teve um grande impacto sobre o Novo Cinema Latino-Americano nos anos 1960 e 1970. Agora, é mais importante pensar sobre personagens singulares que apresentam uma questão em particular para seu mundo, ou que possibilitam 
ano 2 número 4

Dossiê um questionamento do mundo e de seus modos através de suas experiências, partilhando uma ideia comum de entendimento e vivendo no mundo como representação. Isto, em grande medida, agora atravessa a realidade e a investigação da história.

O documentário em geral e os documentários que mencionamos aqui em particular constroem e/ou evocam o presente e o passado com um acúmulo de referências; mas essas referências e perspectivas, tanto individuais quanto coletivas, respondem a situações específicas no espaço e no tempo; aos modos de vida, de ocupar um lugar e um ambiente geográfico, de atravessar a história. Em resumo, os documentários do sul do continente americano intensificam o poder da função fabuladora da experiência registrada. 